\title{
Elaboration of the Model of Evaluating the Transactional Costs Management Efficiency in the Educational Sphere
}

Vorontsova L.V.a

Ismagilova G.N. ${ }^{\text {b }}$

Kramin T.V.c

Timiryasova A.V.d

\author{
acd Institute of Economics, Management and Law, Kazan, Russian Federation, 420111 \\ ${ }^{b}$ Kazan Federal University, Institute of Management, Economics and Finance, Kazan, 420008, Russia
}

\section{Doi:10.5901/mjss.2015.v6n1s3p136}

\section{Abstract}

The article is devoted to elaboration of tools for transactional costs management in the educational sphere of Russia. The work uses space-temporal classification of transactional costs of an organization, takes into account the impact of institutional environment upon transactional costs, and formulates the model of evaluating the efficiency of the main transactional costs management in the educational sphere in Russia.

Keywords: managerial tools, transactional costs, educational establishment, institutional environment, benchmarking

At present, the Russian educational system actively integrates into the European educational system, introduces and adapts international standards within the framework of Bologna process (De Wit, 2006; Pursiainen \& Medvedev, 2005). Russia's joining the World Trade organization creates additional possibilities for foreign educational establishments in Russia, providing Russia's further integration into the international labor division system (Gaponenko, 2004; Gounko \& Smale, 2007; Колесов, 2006). Competition grows both in the educational services ${ }^{1}$ market (Johnson, 2013) and in the labor market of Russia, which becomes more mobile and competitive (Ворошилова, 2002).

These conditions and processes generate new requirements for the competitiveness level of the Russian educational sector. Consequently, it is necessary to reveal and use the sources of efficiency growth of the Russian educational establishments.

The presented work is devoted to forming the model of evaluating of transactional costs management in the educational sphere.

Revealing, accounting and managing the transactional costs is traditionally a very complex task. Transactional costs are intangible, but the objectives of their management are tangible - we are to reduce the material loses caused by transactional costs (Dietrich, 2008; Groenewegen, 1996; Т. Крамин, 2006). Thus, it is necessary to estimate the economic effect of transactional costs management (Крамин, 2007). The work is devoted to elaborating the tools of transactional costs management in an educational establishment.

According to some researchers, transactional costs are based on information (Крамин, 2007; Олейник, 2005; Сафиуллин \& Сафииллина, 2007; Скоблева, 2010). Actually they are determined by some information, its completeness and quality, speed of distributing and level of automatization, the degree of its asymmetry, etc.

Thus, to systematically reveal the transactional costs of an organization, it is necessary to thoroughly research its informational system, the processes of formation, distribution and using the information, both within the organization and when its interaction with the environment (Davis, North, \& Smorodin, 1971; Mühlfeld, 2004; Williamson, 1991). If the information reaches the decision-maker in due time and with due quality, then the transactional costs will be minimal. By modelling information streams, revealing the stages of forming and transferring of information, we have built the classification of transactional costs (Воронцова, Крамин, \& Крамин, 2011) (see Table 1).

The types of transactional costs in Table 1 are marked with the Roman numerals. Group I of transactional costs, for instance, corresponds to the external transactional costs, occurring at the stage of information forming.

1 See for instance (Marginson, 2006). 
Table 1. Overall space-temporal classification of transactional costs.

\begin{tabular}{|l|c|c|c|}
\hline Sphere \Stage & Information forming & Information distribution & Use of information \\
\hline External transactional costs & $\mathrm{I}$ & $\mathrm{II}$ & $\mathrm{III}$ \\
\hline Internal transactional costs of Human Capital management & $\mathrm{IV}$ & $\mathrm{V}$ & $\mathrm{VI}$ \\
\hline Internal transactional costs of processes management & $\mathrm{VII}$ & $\mathrm{VIII}$ & $\mathrm{IX}$ \\
\hline
\end{tabular}

Previous research was devoted to systematization and accounting of internal transactional costs (Воронцова et al., 2011; T. Крамин, 2006). This work views external transactional costs of educational establishments, which determine the transactional costs of educational sphere in general.

Special attention should be paid to Group I of the presented classification (further - TC1). The transactional costs of this group can also be structured. They include:

1) current costs of obtaining external information for creating teaching programs and materials, for professional development of personnel, for access to libraries, databases of statistical services and informational and analytical agencies, etc.;

2) costs of obtaining information, connected with learning the experience of advanced educational establishments, with forming competences from the Russian and foreign best practices, during benchmarking technologies implementation;

3) costs for elaboration and introducing own innovations in the sphere of educational technologies, taking account of national and regional features.

Such division of TC corresponds to the structure of intellectual capital management of an educational establishment: the first group is aimed at development of the existing intellectual capital, the second - at using the intellectual capital of other organizations, at the transfer of educational technologies and competences; the third one corresponds to the creation of the new elements of intellectual capital.

The transactional costs of Group II (TC2) are connected with providing information streams between the subjects of the educational services market, and development of communication systems. Such costs, for example, include the costs for communication networks, equipment and laboratories construction, exchange and mutual analysis of professional information by the personnel of different educational establishments; teaching English to the personnel of educational establishments so that they could read foreign books and articles in their sphere; teaching the personnel to work with software necessary to transform and systematize the data of foreign sources.

The special place in the described structure belongs to the costs of the third group (TC3). They are the costs of creating institutions for innovations commercialization: creating and functioning of the infrastructure of innovations forming (small innovative enterprises at universities, innovative and scientific-educational clusters, including technology towns and technology parks).

In the model of evaluating the efficiency of transactional costs management in educational sphere, the calculation and analysis are subdivided into two stages:

1) calculation of the absolute and relative indicators of particular managerial decisions' efficiency in the sphere of transactional costs management;

2) comparing the obtained indicators with the corresponding data of subjects showing better (or more typical for the sector) result.

The first stage is implemented on the basis of scenario analysis. Typically two scenarios are considered: the first, when there is no activity for transactional costs management (the scientific and educational processes stay intact); in the second scenario the activity is implemented with appropriate costs and effects.

The example of such activity can be financing by the regional authorities of the access to international library funds for all higher educational establishments of the region. The proposed result is the increase of researchers' publishing activity, the increase of popularity of the regional scientific schools, the stimulation of scientific exchange and joint scientific-applied projects it foreign colleagues.

It should be highlighted that the proposed result will, in turn, be very sensitive to some other factors, like the degree of mastering English by university lecturers. Besides, the structure, culture and style of presenting the scientific results in Russia and abroad differ significantly, which is especially vivid in the humanities. This is a great obstacle for activating of publishing the Russian researchers' works abroad. These problems can be solved within one particular university, but at national or regional level they can be solved with much lower transactional costs. That is why the managerial decision on transactional costs management should always be of complex character and undergo a multi-level preliminary preparation. 
The presented managerial decision can be viewed as a "project". Making and implementing the managerial decision corresponds to approving and implementing a project, and vice versa. The difference in investment costs in the two described scenarios is viewed as conditional investment costs of a project, while the difference in cash flows of these scenarios - as a project cash flow.

For such project all traditional indicators of investment projects efficiency are calculated, including the net modified effect of the project, the pay-off period, the internal profitability norm and profitability index.

At the second stage, the calculated indicators are used for benchmarking procedure as the universal tool for evaluating and comparing educational services. For the complex investigation of the model of evaluation the efficiency of transactional costs management in educational sphere, it is necessary to describe the modern benchmarking mechanisms.

Benchmarking originates from the 1950-s when the Japanese started to study the activity of the most successful American companies. However, benchmarking has not gained due popularity in Russia yet.

In 1993 benchmarking centers in the USA and Europe decided to unite their efforts for its development an in 1994 established Global Benchmarking Network, (GBN), which nowadays includes centers in twenty countries. Russia became a member of GBN in autumn 2004 (Kramin, Safiullin, Kramin, \& Timiryasova, 2014).

Having undergone several stages of development, nowadays benchmarking is viewed as an international tool for business-information exchange. This is due to the appearance of organizations engaged in searching partners for reference comparison, which a well-known American marketer Philip Kotler called "industrial dating agencies". In many countries the benchmarking programs are developed with the state support. Their experience shows that such exchange is beneficial for both the enterprises and economy as a whole.

Table 2. Classification of benchmarking types by the object of comparing

\begin{tabular}{|c|c|c|}
\hline Benchmarking type & Object of comparing & Appropriateness of use \\
\hline Strategic benchmarking & $\begin{array}{l}\text { Strategic decisions, techniques of } \\
\text { their making and implementation }\end{array}$ & $\begin{array}{l}\text { 1. Changing strategy in case of changing the external } \\
\text { conditions. } \\
\text { 2. Orientation towards long-term results. Preparedness of } \\
\text { the university for global change. } \\
\text { 3. The main objective is mastering the best practice. }\end{array}$ \\
\hline Process benchmarking & Industrial and business processes & $\begin{array}{l}\text { 1. Necessity to change the key educational processes. } \\
\text { Availability of the potential for their modelling. } \\
\text { 2. Orientation towards short-tern results. Possibility to } \\
\text { model processes. } \\
\text { 3. The main objective is mastering the best practice. }\end{array}$ \\
\hline $\begin{array}{l}\text { Benchmarking of } \\
\text { indicators }\end{array}$ & One or more measurable indicators & $\begin{array}{l}\text { 1. Necessity to achieve the key indicators of } \\
\text { competitiveness. } \\
\text { 2. Sufficiency of local changes. } \\
\text { 3. The main objective is to achieve the key indicators. }\end{array}$ \\
\hline $\begin{array}{l}\text { Benchmarking of } \\
\text { institutions }\end{array}$ & $\begin{array}{l}\text { Internal institutions of educational } \\
\text { establishments }\end{array}$ & $\begin{array}{l}\text { 1. Necessity to change the internal institutional } \\
\text { environment. } \\
\text { 2. The main objective is to form the beneficial institutional } \\
\text { environment. }\end{array}$ \\
\hline
\end{tabular}

To reveal the nature and more complete classification of Group I transactional costs and to elaborate the model of evaluating the transactional costs management efficiency in the educational sphere, we have reviewed and broadened the existing classifications of benchmarking, revealed the causes of its low popularity in Russia, and studied the earlier models of benchmarking implementation.

The broadened classifications of benchmarking based on classifications given in (Alstete, 1995; Hämäläinen, Hämäläinen, Jessen, Kaartinen-Koutaniemi, \& Kristoffersen, 2002; Karjalainen, Kuortti, \& Niinikoski, 2002; Подопригора, 2011), are shown in Tables 2,3.

In Table 2, in addition to earlier classifications, we extinguish benchmarking of institutions, aimed at revealing the best practice in the sphere of internal institutional environment functioning, which is considered to be one of the essential factors of an organization competitiveness under modern conditions. 
Table 3. Classification of benchmarking by the partner status

\begin{tabular}{|c|c|c|}
\hline Benchmarking type & Object of comparing & Conditions and appropriateness of use \\
\hline $\begin{array}{l}\text { Competitive } \\
\text { benchmarking }\end{array}$ & $\begin{array}{l}\text { Competitive positions of competing } \\
\text { universities }\end{array}$ & $\begin{array}{l}\text { Agreements with competitors and existence of a third party for } \\
\text { observe the benchmarking "Code of conduct". Lack of } \\
\text { successful experience at the university. } \\
\text { The main objective is to achieve the key indicators. }\end{array}$ \\
\hline Internal benchmarking & $\begin{array}{l}\text { Indicators of efficient work of } \\
\text { structural subdivisions inside the } \\
\text { educational establishment. }\end{array}$ & $\begin{array}{l}\text { Existence of several structural subdivisions, showing excellent } \\
\text { results. Preparedness for evaluating and changing of the } \\
\text { corporate policy. } \\
\text { The main objective is to improve the current indicators. }\end{array}$ \\
\hline $\begin{array}{l}\text { Functional-sectoral } \\
\text { benchmarking }\end{array}$ & $\begin{array}{l}\text { Indicators of functional efficiency: } \\
\text { sales of services, supply, } \\
\text { personnel management, etc. }\end{array}$ & $\begin{array}{l}\text { Impossibility to violate the law on confidential information. } \\
\text { Preparedness for the complex adaptation process. Possibility to } \\
\text { create non-standard approaches. } \\
\text { The main objective is to achieve the key indicators. }\end{array}$ \\
\hline $\begin{array}{l}\text { Inter-sectoral } \\
\text { benchmarking }\end{array}$ & $\begin{array}{l}\text { Positions of organizations in other } \\
\text { sectors }\end{array}$ & $\begin{array}{l}\text { Lack of successful experience in educational sector. Search for } \\
\text { innovations. } \\
\text { The main objective is mastering the best practice. }\end{array}$ \\
\hline Integrative benchmarking & $\begin{array}{l}\text { Integrative characteristics of } \\
\text { activity of educational } \\
\text { establishments }\end{array}$ & $\begin{array}{l}\text { Necessity to develop state-private partnership, various forms of } \\
\text { integration and interaction in the functioning of educational } \\
\text { establishments, e.g. in clusters. } \\
\text { The main objective is mastering the best practice. }\end{array}$ \\
\hline $\begin{array}{l}\text { International } \\
\text { benchmarking }\end{array}$ & $\begin{array}{l}\text { Positions of foreign educational } \\
\text { establishments }\end{array}$ & $\begin{array}{l}\text { Lack of successful experience in this country. A partner in } \\
\text { another country. Unlimited resource base. } \\
\text { Preparedness for language problems and overcoming cultural } \\
\text { differences. } \\
\text { The main objective is achieving the leading positions in the } \\
\text { world. }\end{array}$ \\
\hline
\end{tabular}

In Table 3, to develop the earlier classifications, we highlight the integrative benchmarking, aimed at revealing the best practice in the sphere of integrative interaction and partnership development of educational establishments, and development of the corresponding external institutions.

The low popularity of benchmarking in Russia is due to several objective reasons. M.G. Podoprigora has marked several of them (Подопригора, 2011):

- unpreparedness of managers of educational establishments to participate in disclosing information;

- $\quad$ high costs and relative slow pay-off of benchmarking;

- lack of experienced benchmarking specialists in Russia;

- functional confusion and unclear objective-setting for benchmarking;

- errors and risks when choosing a reference company;

- problems of estimation of intangible indicators, such as tam spirit, level of comfort in the collective, degree of attention towards consumers of educational services, etc.;

- lack of understanding of objectives and one's own role in achieving them by the managers and personnel;

- violations in implementation of benchmarking mechanism ("The Code of benchmarking"), like using illegal ways in searching and using information; asymmetry in information exchange, etc; violation of agreements on confidentiality.

The presented research results allow to thoroughly systematize and specify the transactional costs of educational establishments in the sphere of benchmarking, which belong to group I of transactional costs according to the above classification.

\section{References}

Alstete, J. W. (1995). Benchmarking in Higher Education: Adapting Best Practices To Improve Quality. ERIC Digest.

Davis, L. E., North, D. C., \& Smorodin, C. (1971). Institutional change and American economic growth: CUP Archive.

Varlamova J.A., Larionova N.I. Economic behavior of households: cross-country comparison. Life Science Journal 2014; 11(6s): 409413.

De Wit, H. (2006). European integration in higher education: the Bologna process towards a European higher education area 
International handbook of higher education (pp. 461-482): Springer.

Dietrich, M. (2008). Transaction Cost Economics and Beyond: Toward a New Economics of the Firm: Taylor \& Francis.

Johnson, M. (2013). Higher Education Competition and Regional Networks in Russia and Central Eurasia. Higher Education in the Global Age: Policy, Practice and Promise in Emerging Societies, 70.

I.Sh. Khasanov, Three-sector structure of the national economy of Russia // Asian Social Science, Volume 10, 2014, Pages 217-224.

Vakhitova T.M., Gadelshina L.A. Directions of the region transport infrastructure development in the context of its competitiveness // Mediterranean Journal of Social Sciences vol. 5 № 24, November 2014, pp. 313-316.

Karjalainen, A., Kuortti, K., \& Niinikoski, S. (2002). Creative Benchmarking: Designing Sustainable International Cooperation in Higher Education: University Press.

Marginson, S. (2006). Dynamics of national and global competition in higher education. Higher Education, 52(1), 1-39.

Mühlfeld, K. S. (2004). Strategic Shifts Between Business Types: A Transaction Cost Theory-based Approach Supported by Dyad Simulation: DUV.

Pursiainen, C., \& Medvedev, S. (2005). The Bologna process and its implications for Russia: the European integration of higher education: Russian-European Centre for Economic.

Kramin, M., Safiullin, L., Kramin, T., \& Timiryasova, A. (2014). Drivers of economic growth and investment attractiveness of Russian regions. Life Science Journal, 11(6s).

Williamson, O. E. (1991). Comparative economic organization: The analysis of discrete structural alternatives. Administrative science quarterly, 269-296.

Safiullin, L., \& Safiullina, G. (2007). Informatsionnaya model upravleniya vosproizvodstvom kachestvennoy rabochey silyi. Aktualnyie problemyi ekonomiki i prava(4), 26-32.

Garifova L.F. Tendencies of small business development in the Russian information economy. // Mediterranean Journal of Social Sciences vol. 5 № 24, November 2014, pp. 336-340. 